\title{
Studies in the Stypella vermiformis group (Auriculariales, Basidiomycota)
}

\author{
Viacheslav Spirin (D) - Vera Malysheva • Danny Haelewaters · Karl-Henrik Larsson
}

Received: 27 June 2018/Accepted: 30 November 2018/Published online: 8 December 2018

(C) The Author(s) 2018

\begin{abstract}
Stypella vermiformis is a heterobasidiomycete producing minute gelatinous basidiocarps on rotten wood of conifers in the Northern Hemisphere. In the current literature, Stypella papillata, the genus type of Stypella (described from Brazil), is treated as a taxonomic synonym of $S$. vermiformis. In the present paper, we revise the type material of $S$. papillata and a number of specimens addressed to $S$. vermiformis. As a result, the presumed synonymy of $S$. papillata and $S$. vermiformis is rejected and the genus Stypella is restricted to the single species $S$. papillata. Morphological and molecular phylogenetic studies of specimens from the Northern Hemisphere corresponding to the current concept of $S$. vermiformis uncovered
\end{abstract}

\section{Spirin $(\bowtie)$}

Botany Unit (Mycology), Finnish Museum of Natural

History, University of Helsinki, P.O. Box 7,

00014 Helsinki, Finland

e-mail: viacheslav.spirin@helsinki.fi

V. Spirin · K.-H. Larsson

Natural History Museum, University of Oslo,

P.O. Box 1172, Blindern, 0318 Oslo, Norway

\section{Malysheva}

Komarov Botanical Institute, Russian Academy of Sciences, Prof. Popova Str. 2, St. Petersburg, Russia 197376

\section{Haelewaters}

Department of Botany and Plant Pathology, Purdue University, 915 W. State Street, West Lafayette, IN 47907, USA three species from two newly described genera. $S$. vermiformis s.str. is distributed in temperate Europe and has small-sized basidia and basidiospores, and it is placed in a new genus, Mycostilla. Another genus, Stypellopsis, is created for two other species, the North American Stypellopsis farlowii, comb. nov., and the North European Stypellopsis hyperborea, sp. nov. Basidia and basidiospores of Stypellopsis spp. are larger than in Mycostilla vermiformis but other morphological characters are very similar. In addition, Spiculogloea minuta (Spiculogloeomycetes, Pucciniomycotina) is reported as new to Norway, parasitising basidiocarps of $M$. vermiformis and Tulasnella spp.

Keywords 5 new taxa $\cdot 4$ new typifications . Heterobasidiomycetes · Phylogeny

\section{Introduction}

The Heterobasidiomycetes are an artificial group of fungi encompassing basidiomycetous taxa with septate basidia and (or) repetitive basidiospores (Weiss et al. 2004a). Their traditional division was based on features of basidial septation and sterigmata (Tulasne and Tulasne 1873) and survived almost unchanged for over a century. First studies on cell ultrastructure (Bandoni 1984) and then DNA studies (Fell et al. 2000; Weiss and Oberwinkler 2001; Bauer et al. 2006) 
questioned the reliability of these morphological characters for a higher-level taxonomy of basidiomycetes. Currently, the class and order arrangement of heterobasidiomycetes is more or less well-established (summarized in McLaughlin and Spatafora 2014). However, their lower-level taxonomy remains unstable, often due to the lack of sequence data or reference material (Liu et al. 2015; Wang et al. 2015). In many cases, this is also a result of a high morphological similarity of taxa appearing unrelated or only distantly related in phylogenetic studies (Millanes et al. 2011; Liu et al. 2015; Wang et al. 2015). An utmost case of this similarity is dealt with in the present paper.

The genus Stypella was described by Möller (1895) from Brazil for two newly introduced species with four-celled basidia, Stypella papillata and Stypella minor. It was not in use until Donk $(1958,1966)$ accepted it and selected $S$. papillata as the generic type. Next, Martin $(1934,1952)$ synonymized the European species Heterochaetella crystallina Bourdot with S. papillata. It was shown later that Dacrymyces vermiformis Berk. \& Broome was an older name for $H$. crystallina and $S$. papillata as they were understood at that time (Reid 1974). Therefore, Reid (1974) created a new combination, Stypella vermiformis (Berk. \& Broome) D.A. Reid, and placed both H. crystallina and $S$. papillata among its synonyms. This opinion about identity of $S$. vermiformis has been widely accepted in the modern taxonomy of heterobasidiomycetes (Oberwinkler 1982; Reid 1990; Roberts 1998).

In the protologues of $S$. papillata and $S$. minor, Möller (1895: 76) described and illustrated peculiar basidia; in his interpretation, each basidium is a terminal part of a much narrower hyphal segment. Studies of basidial morphology in Exidia nucleata (Schwein.) Burt showed that the hypha-like segment bearing four terminal basidial cells represents an integral part of the basidium in that species-the socalled 'enucleate stalk' (Wells 1964). Various opinions on the taxonomic value of this feature persist in the mycological literature. In particular, Donk (1966) accepted it as an important generic character although he refused to include all taxa with stalked basidia into one genus and considered them as belonging to four genera, Myxarium, Stypella, Protodontia and Heterochaetella (with a few species among incertae sedis). On the contrary, Roberts (1998) placed all species with effused basidiocarps and stalked basidia into a redefined Stypella, whereas he retained the type species of Myxarium, M. nucleatum Wallr., in Exidia. However, none of these authors studied the authentic material of $S$. papillata.

Recent molecular phylogenetic studies (Weiss and Oberwinkler 2001; Wells et al. 2004; Spirin et al. 2017) mostly confirm the generic splitting advocated by Donk (1966). Therefore, the genus Stypella has been limited to the single species, $S$. vermiformis $(=S$. papillata sensu auct.). At the same time, stalked basidia are observed in some other genera of Auriculariales (Wells and Raitviir 1980; Weiss and Oberwinkler 2001; Malysheva and Spirin 2017). Thus, the taxonomic significance of this character may have been overemphasized. In the present paper, material of Stypella vermiformis from Northern Hemisphere is revised based on morphology and DNA data, and new information about $S$. papillata is provided.

\section{Materials and methods}

Morphological study

Collections and type specimens from several herbaria have been studied: University of Helsinki, Finland (H); Botanical Museum of the University of Oslo, Norway (O); University of Hamburg, Germany (HBG); University of Gothenburg, Sweden (GB); Farlow Herbarium at Harvard University, USA (FH); National Museum of Natural History, France (PC), and the private herbarium of Heikki Kotiranta in Helsinki, Finland (H.K.). Herbarium acronyms are given according to Thiers (2018). Morphological study follows Miettinen et al. (2012). The abbreviations used in microscopic descriptions are: L-mean basidiospore length, W-mean basidiospore width, $\mathrm{Q}$ - mean L/W ratio, $\mathrm{n}$-number of basidiospore measurements per specimens studied.

\section{DNA extraction and sequencing}

For DNA extraction, small fragments of dried basidiocarps were used. Extractions were done using the NucleoSpin Plant II Kit (Macherey-Nagel GmbH and Co. KG, Düren, Germany) following the manufacturer's instructions. PCR amplification and sequencing of the nrITS region was performed using primers 
ITS1F (Gardes and Bruns 1993) and ITS4 (White et al. 1990). Primers JS1 (Landvik 1996) and LR5 (Vilgalys and Hester 1990) were used to amplify and sequence approximately $700 \mathrm{bp}$ of nrLSU region. Sequencing was performed with an ABI model 3130 Genetic Analyzer (Applied Biosystems, CA, USA). Raw data were edited and assembled in MEGA 6 (Tamura et al. 2013).

Phylogenetic analyses

For this study, eight nrITS and seven nrLSU sequences were generated. In addition to the sequences published here, 4 nrITS sequences and $43 \mathrm{nrLSU}$ sequences were retrieved from GenBank (www.ncbi.nlm.nih.gov/ genbank/). Sequences were aligned with the MAFFT version 7 web tool (http://mafft.cbrc.jp/alignment/ server/) using the Q-INS-i option for nrITS and nrLSU. Before the phylogenetic analyses, the best-fit substitution models for the alignments (GTR) were estimated based on the Akaike Information Criterion (AIC) using FindModel web server (http://hiv.lanl. gov/content/sequence/findmodel/findmodel.html).

Two different phylogenetic analyses were performed for the nrLSU dataset: (1) Maximum likelihood (ML) analyses were run on the PhyML server v.3.0 (Guindon et al. 2010), with 100 rapid bootstrap (BS) replicates; (2) Bayesian inference analyses (BI) were run using MrBayes 3.2.5 software (Ronquist and Huelsenbeck 2003) for 5 million generations, under a GTR model, with four chains, and trees sampled every 100 generations. To check for convergence of MCMC analyses and to get estimates of the posterior distribution of parameter values, Tracer v1.6 was used (Rambaut et al. 2014). In total, 100,002 trees were read. Credible sets of trees contained 30,093 trees sampled. Burn-in was 1000 iterations. We accepted the result where the ESS (Effective Sample Size) was above 200 and the PSRF (Potential Scale Reduction Factor) was close to 1 . For the nrITS dataset, we only performed ML analyses, again on the PhyML server v.3.0. Newly generated sequences have been deposited in GenBank (Table 1).

Specimens examined (sequenced specimens are marked by asterisk)

Mycostilla vermiformis. France. Aveyron (lectotypes of Heterochaetella crystallina and H. dubia var. psilochaeta, see below). Norway. Vestfold: Larvik, Jordstøyp i Kvelde, Picea abies, 15.IX.2016 Spirin
11096 (infected by Spiculogloea minuta) (O), Vemannsås, P. abies, 30.IX.2018 Spirin 12532 (O). Telemark: Bamble, Rogn, P. abies, 3.XI.2017 Spirin 11800 (O). Møre og Romsdal: Aure, Hermundslia, Pinus sylvestris, 20.III.2004 Oldervik 135.04* (O F188059), Lia, P. sylvestris, 15.VIII.2004 Oldervik 470.04 (O F188160); Nesset, Eikesdalen, P. abies (?), 27.IX.2008 Laessøe (O F69226), P. sylvestris, 28.IX.2017 Spirin 11621* (O). Sør-Trøndelag: Hemne, Gammelsetra, P. sylvestris, 24.X.2004 Oldervik 620.04 (O F187964). Nordland: Grane, Litltuva, P. abies, 6.IX.2011 Svantesson 86 (O F253602), Hattfjelldal, P. abies, 5.IX.2011 Svantesson 89 (O). Russia. Nizhny Novgorod Reg.: Lukoyanov Dist., Panzelka, P. abies, 2.VIII.2017 Spirin 11330* (H). Sweden. Norrbotten: Boden, Blåkölen, P. abies, 19.IX.2010 J. Nordén 6759 (O).

Stypella papillata. Brazil. Santa Catarina: Blumenau, no collecting date, Möller 24 (HBG) (designated here as a lectotype, MBT383478).

Stypellopsis farlowii. Russia. Khabarovsk Reg.: Solnechnyi Dist., Igdomi, Picea ajanensis, 3.IX.2016 Spirin 10901 (H). USA. New Hampshire (holotype, see below). Tennessee: Blount Co., Great Smokey Mts. Nat. Park, Pinus sp., 28.IX.2015 Miettinen 19508.1 (H); Cocke Co.: Cosby, decayed wood, 16.VII.2004 Larsson 12337* (GB, H); Sevier Co.: Great Smokey Mts. Nat. Park, Tsuga canadensis, 30.IX.2015 Miettinen 19579, 19580.2 (H). Washington: Jefferson Co., Morgan Crossing, Tsuga heterophylla, 7.X.2014 Spirin 8254* (H).

Stypellopsis hyperborea. Finland. Pohjois-Karjala: Lieksa, Louhivaara, P. sylvestris, 28.VIII.2002 Junninen 3231 (H.K.), Pankasaari, P. sylvestris, 22.VIII.2002 Junninen 2967 (H.K.). Etelä-Häme: Padasjoki, Vesijako, coniferous wood, 13.IX.2001 Larsson 11751* (GB). Inarin Lappi: Inari, Kessi, $P$. sylvestris, 26.VIII.1991 Kotiranta 8458 (H.K.). Norway. Akershus: Hurdal, Fjellsjøkampen, P. abies, 2.IX.1990 Hallenberg 345/90 (O F295642); Jevnaker, P. abies, IX.2011 J. Nordén 9751*(O). Oppland: Sel, Sagåa Nat. Res., P. abies, 13.IX.2016 Spirin 11061, 11066* (holotype, see below). Hedmark: Løten, Brendkoia, P. sylvestris, 23.IX.1987 Hogholen 280/87 (O F160519). Møre og Romsdal: Aure, Aure, P. sylvestris, 6.XI.2003 Oldervik 564.03 (O F188249), Lia, P. sylvestris, 29.X.2004 Oldervik 640.04 (O F188144), Løvika, P. sylvestris, 10.IX.2003 Oldervik 452.03 (O F189387). Sør-Trøndelag: Meldal, Urvatn, 
Table 1 Data for ITS and nrLSU sequences of Mycostilla/Stypellopsis spp. used in the phylogenetic analyses

\begin{tabular}{|c|c|c|c|c|c|c|}
\hline Species & $\begin{array}{l}\text { Collector/herbarium } \\
\text { number }\end{array}$ & $\begin{array}{l}\text { Origin } \\
\text { (ISO code) }\end{array}$ & Host & $\begin{array}{l}\text { nrLSU } \\
\text { GenBank \# }\end{array}$ & $\begin{array}{l}\text { ITS } \\
\text { GenBank \# }\end{array}$ & Source \\
\hline M. vermiformis & MW 417 & $\mathrm{DE}$ & - & AF291369 & - & $\begin{array}{l}\text { Weiss and Oberwinkler } \\
\text { (2001) }\end{array}$ \\
\hline M. vermiformis & - & US-CA & indoor surface swab & - & KF221899 & Adams et al. (2013) \\
\hline M. vermiformis & - & SE & Picea abies & - & KM493985 & GenBank \\
\hline M. vermiformis & - & SE & soil & - & KU061904 & GenBank \\
\hline M. vermiformis & $\begin{array}{l}\text { Oldervik 135.04 } \\
\text { (O F188059) }\end{array}$ & NO & Pinus sylvestris & - & MG735418 & Malysheva et al. (2018) \\
\hline M. vermiformis & Spirin $11330(\mathrm{H})$ & RU-NIZ & P. abies & MG735425 & MG735417 & Malysheva et al. (2018) \\
\hline M. vermiformis & Spirin $11621(\mathrm{O})$ & $\mathrm{NO}$ & P. sylvestris & MG857098 & MG857093 & this study \\
\hline S. farlowii & Larsson 12337 (GB) & US-TN & decayed wood & MG857099 & MG857095 & this study \\
\hline S. farlowii & Spirin $8254(\mathrm{H})$ & US-WA & Tsuga heterophylla & MG857100 & MG857094 & this study \\
\hline S. hyperborea & Larsson 11751 (GB) & FI & coniferous wood & EU118672 & EU118672 & GenBank \\
\hline S. hyperborea & J. Nordén 9751 (O) & $\mathrm{NO}$ & P. abies & MG857101 & MG857097 & this study \\
\hline S. hyperborea & Spirin $11066(\mathrm{O})$ & NO & P. abies & MG857102 & MG857096 & this study \\
\hline
\end{tabular}

P. abies, 1.X.1991 Bendiksen \& Høiland 64-142 (O F173197), Tydal, P. abies, 19.IX.2011 J. Nordén 9292 (O). Nor-Trøndelag: Snåsa, P. abies, 27.IX.2011 J. Nordén 9692 (O). Nordland: Hattfjelldal, P. abies, 8.IX.2011 Svantesson 192 (O); Rana, Ørtfjellmoen, P. abies, 11.IX.1976 Strid 753/76 (O F160518). Russia. Primorie: Krasnoarmeiskii Dist., Valinku, P. ajanensis, 29.VIII.2013 Spirin $6487(\mathrm{H})$. Sweden. Västergötland: Björketorp, Klippan, $P$. sylvestris, 19.IX.1979 Hjortstam 11028 (O F 160517). Småland: Jönköping, Marieholmsskogen, P. abies, 30.X.2010 J. Nordén 7971 (O).

\section{Results and discussion}

In total, 40 specimens from Europe, East Asia and North America corresponding to the current concept of S. vermiformis (sensu Reid 1990; Roberts 1998) were selected for morphological study. Basidiocarps are initially represented by minute, sharp-pointed, gelatinous outgrowths irregularly arranged on an extremely thin joint subiculum. These outgrowths quickly fuse together and produce compound resupinate basidiocarps of a very characteristic, reticulate appearance (observable under lens) (Fig. 1). The basidiocarp core consists of several tubular, bluntpointed or tapering, thin-walled cystidia up to $220 \mu \mathrm{m}$ long. These giant cystidia are often glued together and covered by sparsely arranged hyphae, basidia and occasionally by cystidia-like cells of smaller size (gloeocystidia). Basidiospores are rather small-sized, broadly ellipsoid to subglobose, repetitive, ca. 3.5-7 × 3-6 $\mu \mathrm{m}$ (Fig. 2). All studied specimens were collected from coniferous wood at advanced decay stages in temperate-boreal forests in the Northern Hemisphere.

The authentic specimen of $S$. papillata (designated as a lectotype in Specimens examined) was detected in HBG by Friedrichsen (1977) and studied by us. This fungus is widely different from $S$. vermiformis. Its fructifications are continuous, not reticulate, and up to $0.5 \mathrm{~mm}$ thick. Microscopically, it is characterized by slightly or distinctly thick-walled and totally clampless hyphae (as illustrated in Möller's original figure) and a presence of globose conidiiferous cells. These cells are arranged in chains connecting with each other by hypha-like outgrowths. Walls of some conidiophores are somewhat shrunken and, if observations are made in normal light and without colouring medium, they make an impression of the inner cell septation (Fig. 2). However, using phase contrast illumination and coloured mountant (Cotton Blue) reveals it merely as an artifact. "Spores" described by Möller (1895) in the protologue of $S$. papillata are in fact broadly ellipsoid or subglobose, slightly thick-walled conidia located on short terminal projections of some conidiiferous cells. A few cystidia-like elements have been 

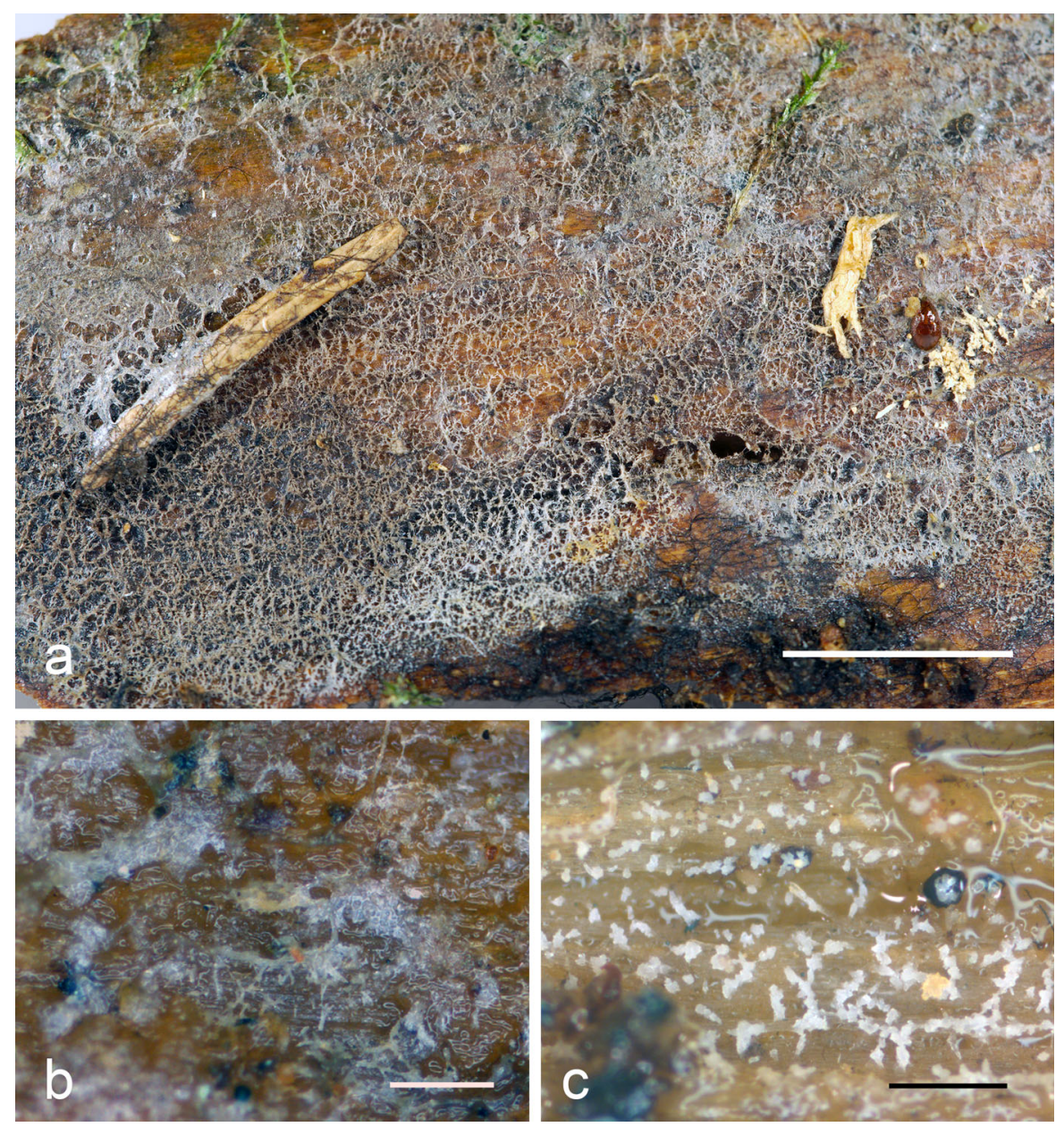

Fig. 1 Basidiocarps of: a Stypellopsis hyperborea (holotype) (scale bar = $5 \mathrm{~mm})$; b S. farlowii (Spirin 8254$)(\mathrm{scale}$ bar $=0.5 \mathrm{~mm})$; c Mycostilla vermiformis (Spirin 11621) (scale bar $=0.5 \mathrm{~mm}$ )

detected in S. papillata, too, but it is uncertain whether they belong to this fungus or another species underneath. In turn, no conidial stage has been detected in specimens of $S$. vermiformis s.l. from Northern Hemisphere, and those collections reveal regularly clamped hyphae. Two anamorphic genera so far detected in the Auriculariales, Helicomyxa R. Kirschner \& Chee J. Chen and Ovipoculum Zhu L. Yang \& R. Kirschner, also possess clamped hyphae (Kirschner and Chen 2004; Kirschner et al. 2010). The only species with clampless hyphae confirmed as a member of the Auriculariales is Endoperplexa enodulosa (Hauerslev) P. Roberts (Weiss et al. 2004b); however, it is not reminiscent of $S$. papillata either. Considering these observations, we reject the synonymy of $S$. papillata and $S$. vermiformis s.l. The identity of $S$. papillata should be re-established based on newly collected and sequenced material from the locus classicus.

Eight collections of Stypella vermiformis s.l. were selected for DNA study, and two datasets were assembled for phylogenetic analyses:

1. A nrLSU phylogeny of the Auriculariales (Fig. 3a). The final aligned dataset included 863 characters (including gaps). The overall topologies of the ML and BI trees were nearly congruent. Specimens of $S$. vermiformis s.l. ended up in two distantly related clades within the order:

A. Stypella vermiformis s.str. clade ( $\mathrm{BS}=100$, $\mathrm{pp}=1$ ) appeared as a sister group of Pseudohydnum gelatinosum although this 

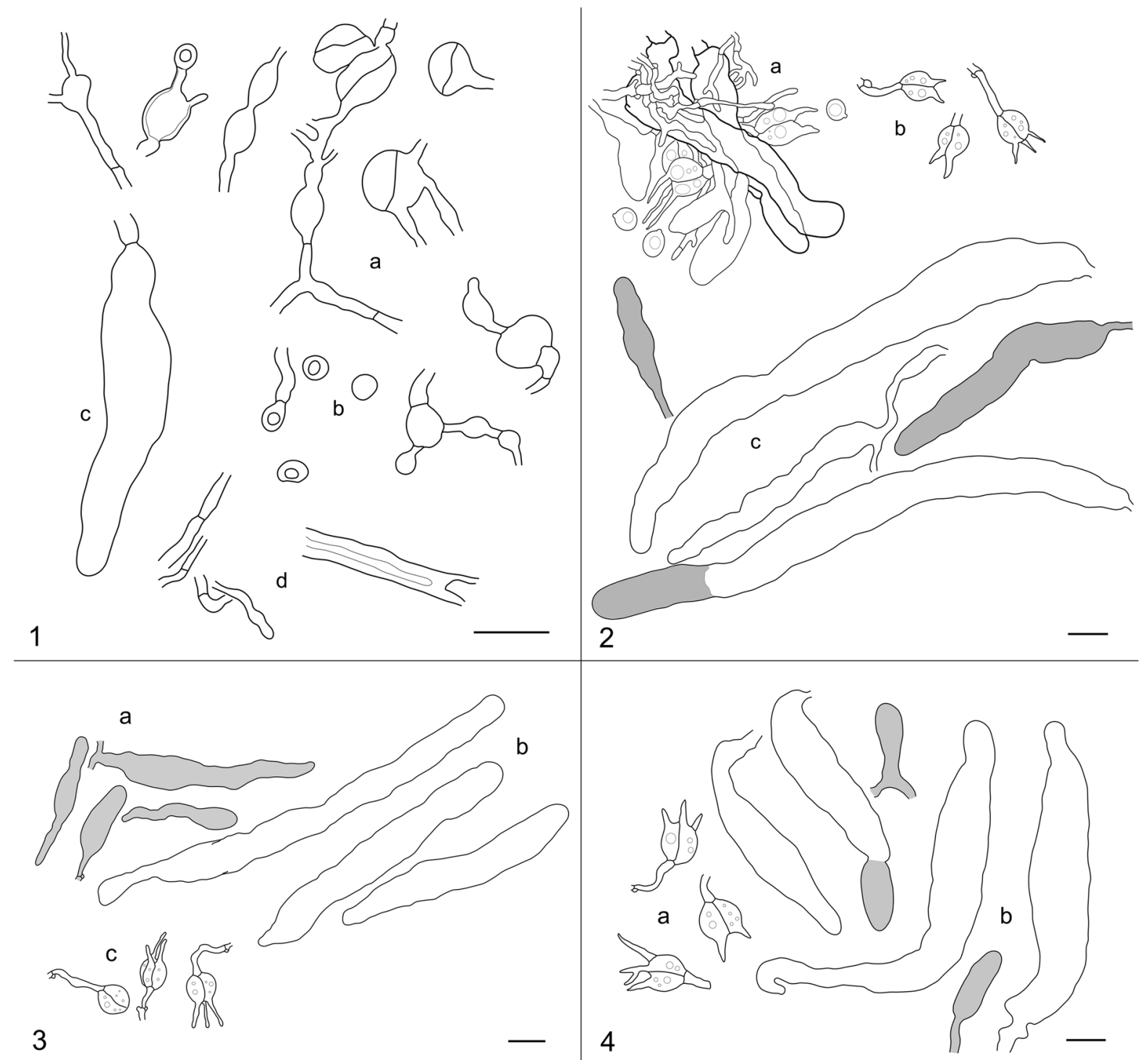

Fig. 2 Microstructures of (1) Stypella papillata (lectotype): a conidiophores (as observed in normal light and $\mathrm{KOH}$ mountant), b - conidia, c - cystidium, d - hyphae; (2) Stypellopsis farlowii: a - hymenial cells, hyphae and basidiospores (Spirin 10901), b-

relationship is supported by Bayesian inference only $(\mathrm{pp}=0.95)$. This clade encompasses specimens collected in temperate forests of Europe. They all possess smallsized basidia and basidiospores and are thus considered conspecific with the type material of S. vermiformis (sensu Reid 1990 and Roberts 1998). Since Stypella is typified with $S$. papillata and not related to $S$. vermiformis,

basidia, c - gloeocystidia and cystidia(Spirin 8254); (3) Mycostilla vermiformis (Spirin 11330): a - gloeocystidia, b cystidia, c - basidia; (4) Stypellopsis hyperborea (holotype): a basidia, $\mathrm{b}-$ gloeocystidia and cystidia. Scale bar $=10 \mu \mathrm{m}$

a new genus, Mycostilla, is introduced for the latter species.

B. Protomerulius farlowii clade $(\mathrm{BS}=99, \mathrm{pp}=$ 1) clusters with a large group of poroid, hydnoid and corticioid species from the genera Protomerulius A. Möller, Heterochaetella (Bourdot) Bourdot \& Galzin and Hyalodon V. Malysheva \& Spirin (see further comments in Malysheva et al. 2018). This clade contains 


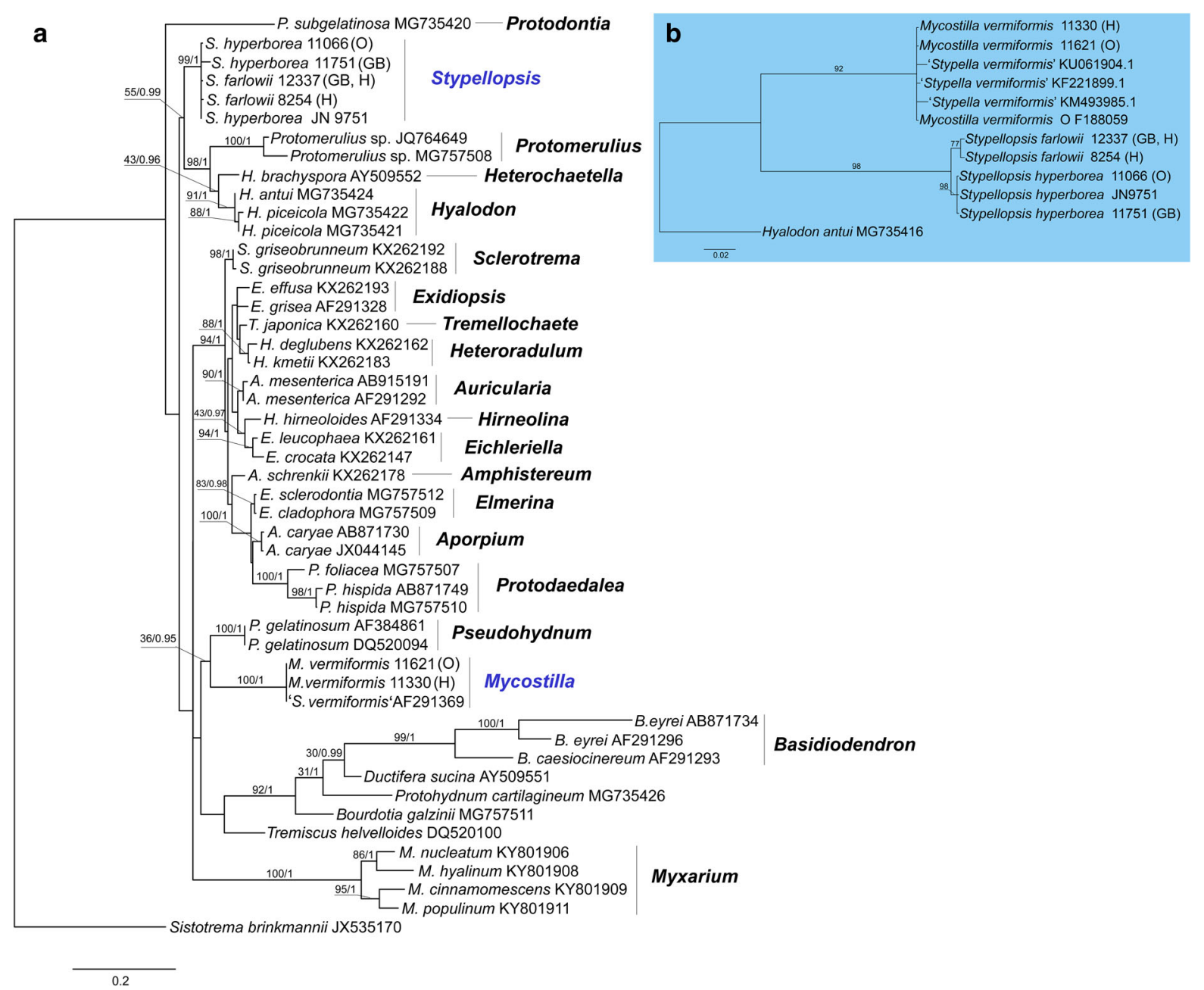

Fig. 3 Phylogenetic relationships of lineages within the Auriculariales: a the best tree from the ML analysis of the nrLSU dataset. ML BS and Bayesian posterior probability (pp) values for internal nodes are given above the branches (BS/pp);

North-American specimens identical to the type specimen of P. farlowii Burt, as well as collections from boreal forests of North Europe. They differ from specimens in the $S$. vermiformis s.str. clade in having larger basidia and basidiospores, and somewhat longer, occasionally tapering cystidia staining brownish in $\mathrm{KOH}$. A new genus, Stypellopsis, is described below to designate this clade.

2. A nrITS phylogeny of the $S$. vermiformis complex (Fig. 3b). The final aligned dataset included 656 characters (including gaps). The ML topology shows two clades with high support (BS > 90\%) b the best tree from the ML analyses of the nrITS dataset. Voucher numbers are given for newly sequenced specimens and accession numbers for additional sequences retrieved from GenBank. Scale bar shows expected changes per site

corresponding to those in the nrLSU phylogeny. Whereas sequences of $M$. vermiformis are highly uniform, the Stypellopsis clade is split in two lineages-North American (BS = 77) and North European (BS $=98)$. Due to observed differences in morphology and geographic distribution, we interpret them as two species, Stypellopsis hyperborea (a new species from North Europe) and Stypellopsis farlowii (based on Protomerulius farlowii from North America). nrITS sequences of these species show a very little inner variation and they are constantly different in six base pairs from each other. Differences in ITS region between most closely related species in the 
Auriculariales may vary from five (Eichleriella shearii-E. macrospora complex) to fifteen base pairs (Heteroradulum deglubens-H. kmetii complex) (Malysheva and Spirin 2017). Therefore, we found the aforementioned genetic difference between $S$. farlowii and $S$. hyperborea sufficient enough to introduce them as separate taxa. Their descriptions are presented below.

Taxonomic changes proposed in our study are summarized in Table 2.

\section{Taxonomy}

Mycostilla Spirin \& V. Malysheva, gen. nov.

\section{$M B 826891$}

Basidiocarps appearing as small gelatinous outgrowths on a hardly visible joint subiculum, later fusing into reticulate compound fructifications. Hyphal structure monomitic, hyphae clamped, subicular hyphae interwoven, subhymenial hyphae ascending. Tramal cystidia tubular, slightly tapering upwards, apically blunt. Gloeocystidia often present, running more or less parallel to tramal cystidia. Cystidia of both types with hyaline content unchanging in $\mathrm{KOH}$. Basidia 2-4-celled, pedunculate, 7-9 $\times 6-8 \mu \mathrm{m}$, with slender, distantly located sterigmata. Basidiospores thin-walled, subglobose, repetitive, 3.5-6 $\times 3-5 \mu \mathrm{m}$, often with one large oil drop.

Type species. Dacrymyces vermiformis Berk. \& Broome.

Mycostilla vermiformis (Berk. \& Broome) Spirin \& V. Malysheva, comb. nov.-Figures 1, 2, 4. $\equiv$ Dacrymyces vermiformis Berk. \& Broome, Ann. Mag. Nat. History 1: 25, 1878. Lectotype. United Kingdom. England: Somerset, Bathford, on wood, 1.IV.1877 Broome 404 (K(M) 47312) (selected by Reid 1974).

\section{MB 826892}

= Heterochaetella crystallina Bourdot, Trans. British Mycol. Soc. 7: 53, 1921. Lectotype. France. Aveyron: Causse Noir, Pinus sp., 22.XI.1914 Galzin 16765 (herb. Bourdot 14157, PC) (designated here, MBT 384443).

= Heterochaetella dubia var. psilochaeta Bourdot \& Galzin, Hyménomycètes de France: 52, 1928. Lectotype. France. Aveyron: Saint-Estève, Juniperus sp., XI.1910 Galzin 7695 (herb. Bourdot 8753, PC) (designated here, MBT 384444).

= Sebacina psilochaeta (Bourdot \& Galzin) L.S. Olive, Bull. Torrey Bot. Club 85: 89, 1958 (invalid combination, ICN Art. 41.1-basionym not indicated).

Basidiocarps gelatinous, first appearing as conical or needle-like outgrowths $0.05-0.2 \mathrm{~mm}$ long, partly fusing, semitranslucent, greyish or with faint pinkish or violaceous tints, later coalescent and producing reticulate compound basidiocarps $0.5-1 \mathrm{~cm}$ in diam. Hyphae clamped; subicular hyphae with distinct walls, 2-3.5 $\mu \mathrm{m}$ in diam., subhymenial hyphae thin-walled, $1-2 \mu \mathrm{m}$ in diam. Tramal cystidia tubular, apically obtuse, $52-140 \times 8-18 \mu \mathrm{m}(\mathrm{n}=20 / 2)$; gloeocystidia tubular to somewhat fusiform, running parallel to tramal cystidia, 16-94 × 4-9 $\mu \mathrm{m}(\mathrm{n}=20 / 2)$. Hyphidia occasionally branched, $1-3 \mu \mathrm{m}$ in diam. Basidia (6.8-) 7.0-8.7 (-8.8) × (5.8-) 6.1-7.6 (-7.8) $\mu \mathrm{m}$ $(n=20 / 2)$, sterigmata only rarely bifurcate,

Table 2 Taxonomic changes proposed in the present study

Taxonomic synonyms of Stypella vermiformis (fide Donk 1966 and Accepted in the present study as

Reid 1974)

Dacrymyces vermiformis Berk. \& Broome

Stypella papillata A. Möller

Heterochaetella crystallina Bourdot

Protomerulis farlowii Burt (Donk 1966-with question mark)
Mycostilla vermiformis (Berk. \& Broome) Spirin \& V. Malysheva

Stypella papillata A. Möller

Mycostilla vermiformis (Berk. \& Broome) Spirin \& V. Malysheva

Stypellopsis farlowii (Burt) Spirin \& K.H. Larss. 
Fig. 4 Basidiospores: a Mycostilla vermiformis (Spirin 11330), b Stypellopsis farlowii (Spirin 8254), c $S$. hyperborea (holotype). Scale bar $=10 \mu \mathrm{m}$
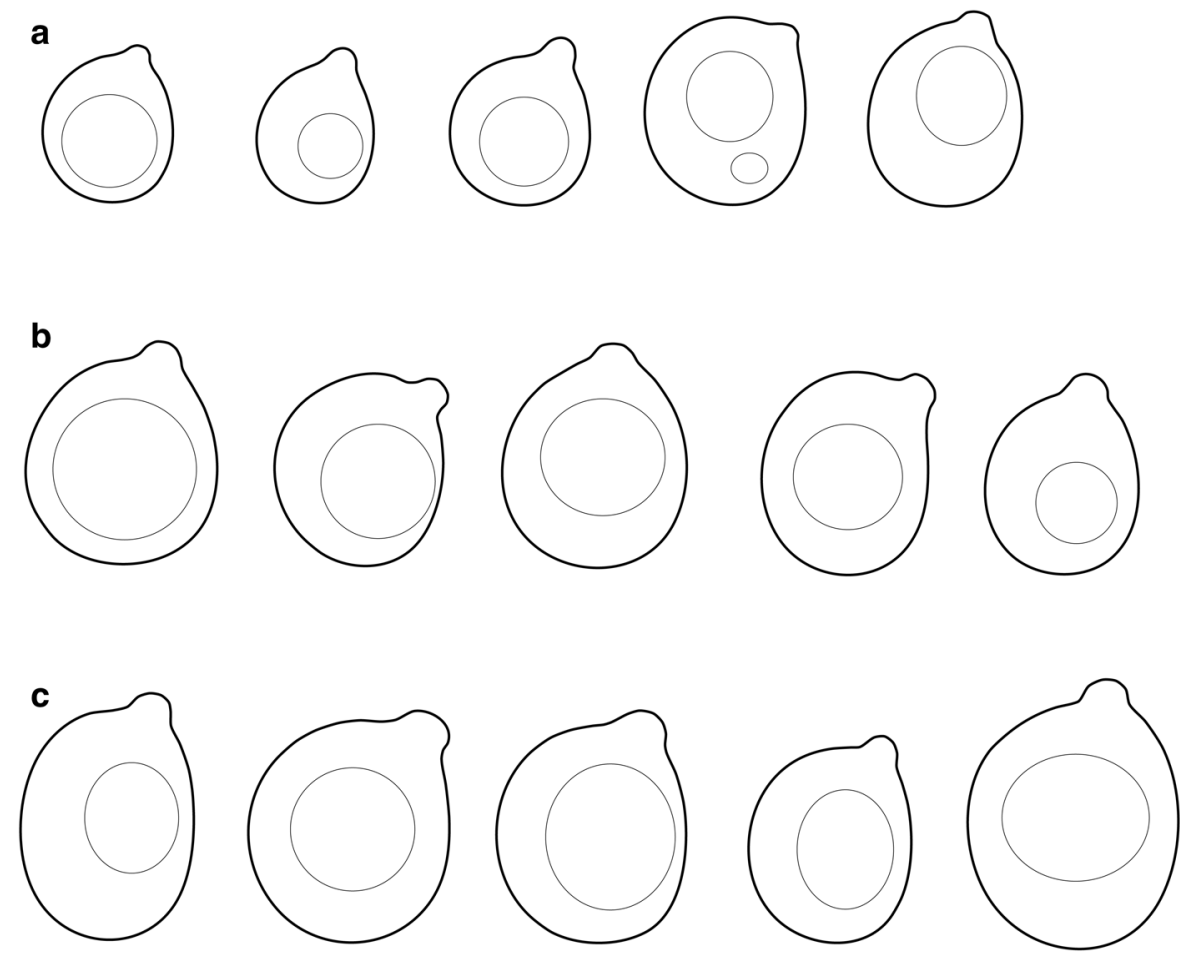

3-16 × 1-2 $\mu \mathrm{m}$, enucleate stalk 4-16 × 1.7-2.8 $\mu \mathrm{m}$. Basidiospores (3.3-) 3.7-5.9 (-6.2) × (2.9-) 3.0-5.2 $(-5.9) \quad \mu \mathrm{m} \quad(\mathrm{n}=160 / 6), \quad \mathrm{L}=4.28-5.22$, $\mathrm{W}=3.72-4.70, \mathrm{Q}=1.10-1.15$.

Remarks. Mycostilla vermiformis is distributed in temperate forests of Europe (Svrček 1950; Hauerslev 1976; Wojewoda 1981; Reid 1990; Roberts 1998). Reid (1974, 1990) studied types of both Dacrymyces vermiformis and Heterochaetella crystallina and concluded that they were conspecific. Smaller basidia and basidiospores help to distinguish $M$. vermiformis from the similarly looking Stypellopsis species. Brownish colouration of cystidial content in $\mathrm{KOH}$ can help in identification of recent Stypellopsis spp. samples; this reaction is absent in all specimens of $M$. vermiformis studied by us. Attention should be paid to the age and collecting data of a specimen, nonetheless. We studied and sequenced one specimen of $M$. vermiformis (O F188059) with abnormally large basidia, $7.7-11.2 \times 6.1-8.1 \mu \mathrm{m}$. This basidial size might point towards Stypellopsis spp. However, other microscopic structures of this collection, as well as ITS sequence, are identical to other specimens of $M$. vermiformis. This morphological deviation can possibly be explained as due to unusual fructification time (the specimen was collected in March).

One specimen of $M$. vermiformis from Norway was infected by Spiculogloea minuta P. Roberts (Spiculogloeomycetes, Pucciniomycotina), and this is the first record of this mycoparasite in the country. Spiculogloea minuta was originally described as a parasite of Tulasnella violea (Quél.) Bourdot \& Galzin (Roberts 1997). Another Norwegian record (Akershus: Bærum, Kjaglidalen, 16.IX.2016, Spirin 11125, O) came from $T$. violea, too, and the third one from Tulasnella deliquescens (Juel) Juel (Oppland: Vågå, Veogjelet, 13.IX.2016, Spirin 11081, O). Rödel (2014) reported $S$. minuta as growing in basidiocarps of Phanerochaete sordida (P. Karst.) J. Erikss. \& Ryvarden in Germany, and Spirin et al. (2016) detected it in Hyphoderma argillaceum (Bres.) Donk in European part of Russia. It is still uncertain, however, if $S$. minuta is a single species able to infect various corticioid fungi, or if we are dealing with a complex of several cryptic species. 
Stypellopsis Spirin \& V. Malysheva, gen. nov.

\section{$M B 826893$}

Basidiocarps appearing as small gelatinous outgrowths from a hardly visible subiculum, later fusing into reticulate, compound basidiocarps. Hyphal structure monomitic, hyphae clamped, subicular hyphae embedded in a solid gelatinous matter and almost indiscernable, subhymenial hyphae ascending, some brownish in $\mathrm{KOH}$. Tramal cystidia tubular, slightly or distinctly tapering upwards, apically blunt or sharpened, occasionally somewhat moniliform. Gloeocystidia often present, arising at different levels, irregularly arranged, often pleural. Some cystidia with brownish-coloured contents in $\mathrm{KOH}$. Basidia 2-4celled, pedunculate, $8-11.5 \times 7-11.5 \mu \mathrm{m}$, with slender or rather thick, occasionally branched sterigmata. Basidiospores thin-walled, broadly ellipsoid to subglobose, repetitive, 4.5-7 $\times 4-6 \mu \mathrm{m}$, often with one large oil drop.

Type species. Stypellopsis hyperborea Spirin \& V. Malysheva.

Stypellopsis farlowii (Burt) Spirin \& K.H. Larss., comb. nov.-Figures 1, 2, 4.

$\equiv$ Protomerulius farlowii Burt, Annals Missouri Bot. Gdn. 6: 176, 1919. Holotype. USA. New Hampshire: Carroll Co., Chocorua, very rotten coniferous wood, IX.1918 Farlow 6 + (FH 00488287). Epitype. USA. Tennessee: Cocke Co.: Cosby, decayed wood, 16.VII.2004 Larsson 12337 (GB) (designated here, MBT383479).

\section{$M B 826894$}

Basidiocarps gelatinous, first appearing as needle-like, then fimbriate outgrowths $0.05-0.2 \mathrm{~mm}$ long, partly fusing, semitranslucent, whitish or with faint violaceous tints, later coalescent and producing reticulate compound basidiocarps $0.5-1 \mathrm{~cm}$ in diam. Hyphae clamped, thin-walled, $1.5-3 \mu \mathrm{m}$ in diam., some brownish in $\mathrm{KOH}$. Tramal cystidia tubular, tapering to somewhat moniliform or obtuse, some brownish in $\mathrm{KOH}, 60-220 \times 8-18 \mu \mathrm{m}(\mathrm{n}=25 / 3)$; hymenial cystidia (gloeocystidia) clavate to tapering, some pleural, irregularly arranged, 16-44 $\times 4-8 \mu \mathrm{m}$. Hyphidia occasionally branched, $0.5-3 \mu \mathrm{m}$ in diam. Basidia (7.3-) 8.0-10.3 (-10.6) × (7.0-) 7.1-8.8 (-9.1) $\mu \mathrm{m}$, sterigmata only rarely branched, 3-11 $\times 1-2 \mu \mathrm{m}$, enucleate stalk 3-16 × 2-3 $\mu \mathrm{m}$. Basidiospores (4.3-) 4.6-6.1 (-6.2) × (4.0-) 4.1-5.2 (-5.3) $\mu \mathrm{m}(\mathrm{n}=150 / 5)$, $\mathrm{L}=5.29-5.38, \mathrm{~W}=4.62-4.84, \mathrm{Q}=1.10-1.17$.

Remarks. Burt (1919) mistook shallow pits of a compound, reticulate basidiocarp of this species for minute pores and thus described it as a poroid fungus (see also Martin 1952). We made recent collections of this species from North America, which are identical to the type material as described by Burt (1919). Due to scantiness of the P. farlowii holotype, we decided to designate an epitype here. Basidiospores of Stypellopsis farlowii are on average larger than in $M$. vermiformis and smaller than in S. hyperborea. LuckAllen (1960) reported a number of collections from Northeastern USA and Canada identified as Stypella papillata. In fact, they may belong to Stypellopsis farlowii.

Stypellopsis hyperborea Spirin \& V. Malysheva, sp. nov.-Figure 1, 2, 4.

Holotype. Norway. Oppland: Sel, Sagåa Nat. Res., Picea abies, 13.IX.2016 Spirin 11066 (O).

Etymology. Hyperboreus (Lat., adj.)—northern.

\section{MB 826895}

Basidiocarps gelatinous, first appearing as conical or needle-like outgrowths $0.05-0.3 \mathrm{~mm}$ long, then fimbriate, partly fusing, semitranslucent, whitish or with faint violaceous tints, later coalescent and producing reticulate compound basidiocarps $0.5-4 \mathrm{~cm}$ in diam. Hyphae clamped, thin-walled, 1-2.5 $\mu \mathrm{m}$ in diam., some brownish in $\mathrm{KOH}$. Tramal cystidia tubular, tapering to somewhat moniliform or obtuse, some brownish in $\mathrm{KOH}, 60-210 \times 9-17.5 \mu \mathrm{m}(\mathrm{n}=32 / 3)$; hymenial cystidia (gloeocystidia) clavate to tapering, some pleural, irregularly arranged, 14-32 × 4-12 $\mu \mathrm{m}$. Hyphidia occasionally branched, $0.5-2 \mu \mathrm{m}$ in diam. Basidia (9.2-) 9.3-11.3 $(-11.8) \times(7.8-) \quad 8.0-11.4(-12.1) \mu \mathrm{m}$, sterigmata occasionally branched, $5-19 \times 1.8-3 \mu \mathrm{m}$, enucleate stalk 7-30 × 2-3.5 $\mu \mathrm{m}$. Basidiospores (4.8-) 5.1-7.0 $(-7.1) \times(4.0-) \quad 4.1-5.9 \quad(-6.2) \quad \mu \mathrm{m} \quad(\mathrm{n}=200 / 7)$, $\mathrm{L}=5.77-6.07, \mathrm{~W}=4.89-5.21, \mathrm{Q}=1.14-1.19$.

Remarks Stypellopsis hyperborea possesses the largest basidiospores of the species complex. It seems to be a truly boreal species distributed in coniferous forests of North Europe. The description and microscopic drawing of Stypella vermiformis by Strid (1986) refer to this species. 
Acknowledgements Open access funding provided by University of Helsinki including Helsinki University Central Hospital. Mattias Schultz kindly helped to the author VS during his study of A. Möller's collections in HBG. Donald H. Pfister (Farlow Herbarium, USA) assisted us with study of the $P$. farlowii holotype. Jenni Nordén (Oslo, Norway) and Heikki Kotiranta (Helsinki, Finland) provided us with valuable collections.

Author's contribution VS: collecting fungal specimens, microscopic study, writing manuscript; VM: DNA extraction and sequencing, phylogenetic analyses, writing manuscript; $\mathrm{DH}$ : microscopic study, writing manuscript; KL: collecting fungal specimens, phylogenetic analyses, final editing of the manuscript.

Funding Viacheslav Spirin and Karl-Henrik LarssonNorwegian Biodiversity Information Centre (project "A survey of Norwegian jelly fungi", Grant Number knr. 44-15); Vera Malysheva-Komarov Botanical Institute (project "Biodiversity and spatial structure of fungi and myxomycetes communities in natural and anthropogenic ecosystems", grant number AAAA-A18-118031290108-6).

Conflict of interest The authors declare that they have no conflict of interest.

Open Access This article is distributed under the terms of the Creative Commons Attribution 4.0 International License (http:// creativecommons.org/licenses/by/4.0/), which permits unrestricted use, distribution, and reproduction in any medium, provided you give appropriate credit to the original author(s) and the source, provide a link to the Creative Commons license, and indicate if changes were made.

\section{References}

Adams RI, Miletto M, Taylor JW, Bruns TD (2013) The diversity and distribution of fungi on residential surfaces. PLoS ONE 8(11):E78866

Bandoni RJ (1984) The Tremellales and Auriculariales: an alternative classification. Trans Mycol Soc Japan 25:489-530

Bauer R, Begerow D, Sampaio JP, Weiss M, Oberwinkler F (2006) The simple-septate basidiomycetes: a synopsis. Mycol Progress 5:41-66

Burt EA (1919) Protomerulius farlowii Burt, n. sp. Ann Missouri Bot Gdn 6:175-177

Donk MA (1958) The generic names proposed for Hymenomycetes. VIII: Auriculariaceae, Septobasidiaceae, Tremellaceae Dacrymycetaceae. Taxon 7:236-250

Donk MA (1966) Check list of European hymenomycetous Heterobasidiae. Persoonia 4:145-335

Fell JW, Boekhout T, Fonseca A, Scorzetti G, Statzell-Tallman A (2000) Biodiversity and systematics of basidiomycetous yeasts as determined by large-subunit rDNA D1/D2 domain sequence analysis. Int J Syst Evol Microbiol 50:1351-1371

Friedrichsen I (1977) Das Schicksal der von A. Möller in Brasilien (1890-1895) gesammelten Pilze sowie eine Liste der noch vorhandenden Sammlungsstücke. Mitt Inst Allgem Bot Hamburg 15:99-104

Gardes M, Bruns TD (1993) ITS Primers with enhanced specificity for Basidiomycetes - application to the identification of mycorrhizae and rusts. Mol Ecol 2:113-118

Guindon S, Dufayard JF, Lefort V, Anisimova M, Hordijk W, Gascuel O (2010) New algorithms and methods to estimate maximum-likelihood phylogenies: assessing the performance of PhyML 3.0. Syst Biol 59:307-321

Hauerslev K (1976) New and rare Tremellaceae on record in Denmark. Friesia 11:94-115

Kirschner R, Chen CJ (2004) Helicomyxa everhartioides, a new helicosporous sporodochial hyphomycete from Taiwan with relationships to the Hyaloriaceae (Auriculariales, Basidiomycota). Stud Mycol 50:337-342

Kirschner R, Yang ZL, Zhao Q, Feng B (2010) Ovipoculum album, a new anamorph with gelatinous cupulate bulbilliferous conidiomata from China and with affinities to the Auriculariales (Basidiomycota). Fungal Divers 43:55-65

Landvik S (1996) Neolecta, a fruit-body producing genus of the basal ascomycetes, as shown by SSU and LSU rDNA sequences. Mycol Res 100:199-202

Liu XZ, Wang QM, Göker M, Groenewald M, Kachalkin AV, Lumbsch HT, Millanes AM, Wedin M, Yurkov AM, Boekhout T, Bai FY (2015) Towards an integrated classification of the Tremellomycetes. Stud Mycol 81:85-147

Luck-Allen ER (1960) The genus Heterochaetella. Canadian J Bot 38:559-569

Malysheva V, Spirin V (2017) Taxonomy and phylogeny of the Auriculariales (Agaricomycetes, Basidiomycota) with stereoid basidiocarps. Fungal Biol 121:689-715

Malysheva V, Spirin V, Miettinen O, Motato-Vásquez V, Hernawati Seelan JSS, Larsson KH (2018) Revision of Protohydnum (Auriculariales, Basidiomycota). Mycol Progress 17:805-814. https://doi.org/10.1007/s11557-0181393-6

Martin GW (1934) The genus Stypella. State Univ Iowa Stud Nat Hist 16:143-150

Martin GW (1952) Revision of the North Central Tremellales. State Univ Iowa Stud Nat Hist 19:1-122

McLaughlin DJ, Spatafora JW (eds) (2014) The Mycota. VII. Systematics and Evolution. Part A. Springer, Berlin

Miettinen O, Spirin V, Niemelä T (2012) Notes on genus Aporpium (Auriculariales, Basidiomycota), with a new species from temperate Europe. Ann Bot Fennici 49:359-368

Millanes AM, Diederich P, Ekman S, Wedin M (2011) Phylogeny and character evolution in the jelly fungi (Tremellomycetes, Basidiomycota, Fungi). Mol Phyl Evol 61:12-28. https://doi.org/10.1016/j.ympev.2011.05.014

Möller A (1895) Protobasidiomyceten. Bot Mitth Tropen 8:1-180

Oberwinkler F (1982) The significance of the morphology of the basidium in the phylogeny of Basidiomycetes. In: Wells K, Wells EK (eds) Basidium and basidiocarp: evolution, cytology, function and development. Springer, Berlin, pp 9-35 
Rambaut A, Suchard MA, Xie D, Drummond AJ (2014) Tracer v1.6. http://tree.bio.ed.ac.uk/software/tracer/. Accessed on 20 December 2017

Reid DA (1974) A monograph of the British Dacrymycetales. Trans British Mycol Soc 62:433-494

Reid DA (1990) New or interesting records of British Heterobasidiomycetes. Mycol Res 94:94-108

Roberts P (1997) New heterobasidiomycetes from Great Britain. Mycotaxon 63:195-216

Roberts P (1998) A revision of the genera Heterochaetella, Myxarium, Protodontia, and Stypella (Heterobasidiomycetes). Mycotaxon 69:209-248

Rödel T (2014) Über aktuelle Funde von Spiculogloea occulta P. Roberts, Spiculogloea minuta P. Roberts und Spiculogloea subminuta Hauerslev. Ein Beitrag zur Kenntnis der Gattung Spiculogloea. Zeitschrift Mykol 80:401-504

Ronquist F, Huelsenbeck JP (2003) MRBAYE S 3: Bayesian phylogenetic inference under mixed models. Bioinformatics 19:1572-1574

Spirin V, Nordén J, Svantesson S, Larsson KH (2016) New records of intrahymenial heterobasidiomycetes (Basidiomycota) in north Europe. Nordic J Bot 34:475-477

Spirin V, Malysheva V, Larsson KH (2017) On some forgotten species of Exidia and Myxarium (Auriculariales, Basidiomycota). Nordic J Bot 36(3):e01601-1-e01601-11

Strid A (1986) Tremellaceous fungi with small, spiny fruitbodies. Windahlia 16:99-112

Svrček M (1950) Heterochaetella crystallina Bourdot in Bohemia. Česká Mykol 4:39-42

Tamura K, Stecher G, Peterson D, Filipski A, Kumar S (2013) MEGA6: molecular evolutionary genetics analysis version 6.0. Mol Biol Evol 30:2725-2729

Thiers B (2018) Index Herbariorum: a global directory of public herbaria and associated stuff [continuosly updated]. New York Botanical Garden's Virtual Herbarium. http:// sweetgum.nybg.org/ih

Tulasne LR, Tulasne C (1873) New notes upon the tremellineous fungi and their analogues. J Linnean Soc 13:31-42
Vilgalys R, Hester M (1990) Rapid genetic identification and mapping of enzymatically amplified ribosomal DNA from several Cryptococcus species. J Bacteriol 172:4238-4246

Wang QM, Groenewald M, Takashima M, Theelen B, Han PJ, Liu XZ, Boekhout T, Bai FY (2015) Phylogeny of yeasts and related filamentous fungi within Pucciniomycotina determined from multigene sequence analyses. Stud Mycol 81:27-53

Weiss M, Oberwinkler F (2001) Phylogenetic relationships in Auriculariales and related groups-hypotheses derived from nyclear ribosomal DNA sequences. Mycol Res 105:403-415

Weiss M, Bauer R, Begerow D (2004a) Spotlights on heterobasidiomycetes. In: Agerer R et al (eds) Frontiers in Basidiomycote Mycology. IHW, Eching, pp 7-48

Weiss M, Selosse MA, Rexer KH, Urban A, Oberwinkler F (2004b) Sebacinales: a hitherto overlooked cosm of heterobasidiomycetes with a broad mycorrhizal potential. Mycol Res 108:1003-1010

Wells K (1964) The basidia of Exidia nucleata. II. Development. Am J Bot 51:360-370

Wells K, Raitviir A (1980) The genus Eichleriella (Tremellaceae) of the USSR. Mycologia 72:564-577

Wells K, Bandoni RJ, Lim SR, Berbee ML (2004) Observations on some species of Myxarium and reconsideration of the Auriculariaceae and Hyaloriaceae (Auriculariales). In: Agerer R et al (eds) Frontiers in Basidiomycete Mycology. IHW, Eching, pp 237-248

White TJ, Bruns TD, Lee SB, Taylor JW (1990) Analysis of phylogenetic relationships by amplification and direct sequencing of ribosomal RNA genes. In: Innis MA, Gelfand DH, Sninsky JJ, White TJ (eds) PCR protocols: a guide to methods and applications. Academic Press, San Diego, pp 315-322

Wojewoda W (1981) Mała flora grzybów. Tom 2. Krakow, Państwowe Wydawnictwo Naukowe Warsaw 